\title{
Regulation of nutritive regime of typical black earth at entering defecation residues in conditions of Forest-steppe
}

\author{
A. Sypko, \\ Candidate of Agricultural Sciences, Leading Researcher at the Department of Agricultural \\ Chemistry \\ O. Strilets, \\ Candidate of agricultural science, senior researcher Researcher at the Department of \\ Agricultural Chemistry \\ N. Zatserkovna, \\ Candidate of Agricultural Sciences, Researcher at the Department of Agricultural Chemistry \\ Institute of Bioenergy Crops and Sugar Beet NAAS \\ M. Kostashchuk, \\ Candidate of Agricultural Sciences, \\ G. Mazur, \\ Uladovo-Liulynetska Experimental Breeding Station Institute of Bioenergy Crops and Sugar \\ Beet NAAS
}

The purpose. To study influence of defecation residues gained with the help of new technique in grainbeet crop rotation upon content of primary nutritive elements in typical leached slightly sour black earth. Methods. Physical and chemical agrochemical analysis of soil and phenological observation over growth and development of plants. Results. Use of improver in dose of 1,0 (calculated using index of hydrolytic acidity of soil (4,9 t/hectare in physical weight)) with mineral fertilizer (N90P60K90) in the autumn under disking of stubble with the subsequent ploughing, promotes heightening of content of alkalihydrolyzed nitrogen up to $137,0 \mathrm{mg} / \mathrm{kg}$, mobile phosphorus - up to 201,4 , exchangeable potassium up to $117,3 \mathrm{~kg} / \mathrm{kg}$ of soil that exceeds indexes of control treatments for 11,$0 ; 64,0 ; 53,3 \mathrm{mg}$

$/ \mathrm{kg}$ of soil accordingly. Conclusions. Importation of defecation residues gained with the help of new technique promotes restoration of the content of primary nutritive elements in typical leached slightly sour black earth.

Key words: nutritive regime of soil, improver, defecation residues, soil, technique, alkali-hydrolyzed nitrogen, mobile phosphorus, exchangeable potassium.

Introduction. In the forest-steppe zone of Ukraine, soil is a complex combination of soil formation factors characterized by great diversity. Agrochemical properties of the soil differ, which makes it necessary to apply lime fertilizer in grain-beet crop rotations.

Research on the effect of liming, fertilizer and crop by-products on restoration of degraded dark grey ashed soils found out increasing humus content in the soil from 1.21 to $1.3 \%$, easily hydrolyzed nitrogen from 73 to $118 \mathrm{mg} / \mathrm{kg}$, mobile forms of phosphorus from 105 to $187 \mathrm{mg} / \mathrm{kg}$, exchange potassium from 43 to $122 \mathrm{mg} / \mathrm{kg}$ of soil, therefore promoting optimization of the physical and chemical properties of soil [1-4].

Agronomical value of lime is well-know; however, its conservation value is not less important. Importantly, while optimizing the reaction of medium, nitrogen and phosphate regime also are getting improved. The positive effect of ameliorant on the phosphate soil regime treatment is now known long time. Therefore, when applying full dose of lime it is possible to reduce the dose of nitrogen and phosphate fertilizers by $15-20 \%$. Improving nitrogen nutrition in limed soil is essential and must be taken into account when calculating the dose of nitrogen in order to reduce crop losses and avoid deterioration of the quality. When limed, the soil need in potassium usually increases. At the same time, potassium leaching with infiltration water decreases by $30-40 \%$. The ecological role of liming reveals in the activation 
of beneficial microorganisms, especially nitrogen fixing and nitrifying bacteria, which improve plant nitrogen nutrition $[5,6]$.

Application of half-standard doses of lime on acidic sod-loamy soils improves their agronomic and chemical properties. It increases the content of soluble phosphorus in the soil (by 19.6-34.8\%). Increased content of the soluble phosphorus in soil occurs mainly due to water-soluble loose-bounded phosphorus and aluminium phosphate. While application of fertilizer increases the amount of water-soluble exchange potassium and its mobility, liming, on the contrary, slightly reduces these forms of potassium, however increases the number of non-exchange forms (by 15.4\%) [7].

Proved is a significant effect of high lime doses on phosphate regime in loamy sod-podzolic soils. The mobilizing effect of lime on phosphate was determined at the lime doses calculated by 1.5-2.0 hydrolytic acidity (h.a.). A small dose of lime (h.a. $=0.5$ ) did not improve soil phosphate treatment. Thus, the lime doses of 1.5-2.0 h.a. reduced the need of sod-podzolic soils in phosphate fertilizers. Application of high doses of lime along with small doses of phosphorus fertilizers (superphosphate) may be recommended for poorly cultivated sod-podzolic soils [8].

Under the influence of liming and fertilization, only content of exchange potassium increased significantly. In terms of amount, this form of potassium was 2-3 times smaller than non-exchange and 34 times less that fixed in the treatment without fertilizers. In fertilized and limed treatments, this ratio significantly changed, and against the background of double doses of NPK, non-exchange potassium content was less than the exchange. Liming contributed to increase in non-exchange potassium content of both fertilized and non-fertilized backgrounds. At the same time, liming helped to reduce the content of fixed potassium in the soil against all the fertilization backgrounds. Most likely this occurs due to the fact that calcium replaces potassium and compensates for excess charge on cationic structure fractures and in the caves of vermiculite and smectite packadges. In limed soil, exchange potassium accumulated slowly in the $1 \mathrm{~m}$ soil layer, however, there was specific difference to the depth of $60 \mathrm{~cm}$. This gives reason to believe that liming is capable of preventing / reducing to its minimum potassium loss.

Liming must precede fertilizing on sandy and coherently-sandy soils, increasing their fertility that cannot be restored in any other way. A peculiarity in lime application on these soils is necessity of application not full ameliorant dose at once, but partitioned in order to prevent losses of lime to infiltration $[9,10]$.

The purpose of research was to study the effect of defecation sludge received by the new technology on nutrient regime under the conditions of the Central Forest-Steppe of Ukraine.

Materials and methods. The study was conducted in 2011-2013 at Uladovo-Liulynetska Experimental Breeding Station, Institute of Bioenergy Crops and Sugar Beet NAAS, located in the Central ForestSteppe of Ukraine. Field experiments were conducted in grain-beet crop rotation in typical weakly acidic leached chernozem. Sown area for the experiment was $100 \mathrm{~m}$, accounting area $50 \mathrm{~m}$. Agrochemical characteristics of soil topsoil were as follows: humus $3.3 \%$, total $\mathrm{N} 0.28 \%$, mobile $\mathrm{P} 160.3 \mathrm{mg} / \mathrm{kg}$, exchange $\mathrm{K} 80.4 \mathrm{mg} / \mathrm{kg}$ soil, $\mathrm{pH}_{\sharp} 5.3, \mathrm{H}_{\sharp} 3.96 \mathrm{mg}$ equivalent $/ 100 \mathrm{~g}$ of soil.

To calculate the application rate of ameliorant we accepted the content of the nutrients in dry defecation sludge as following: $\mathrm{CaCO}+\mathrm{MgCO}$ of $84.5 \%, \mathrm{~N} 0.6-0.8 \%, \mathrm{P}-0.7-0.9 \%, \mathrm{KO} 0.7-1.0 \%$ organic matter $13-15 \%$, moisture $3.2 \%$. Ameliorant was applied along with autumn disking of stubble followed by ploughing-in. The doses were calculated by hydrolytic acidity and $\mathrm{pH}_{\sharp}$ values.

To carry out physical, chemical and agrochemical analysis we took samples of soil and plants (for phenological observations) and analyzed them according to method of research in sugar beet [11].

Results. Application of defecation sludge obtained by the new technology in grain-row crop rotation on typical slightly acidic leached chernozem calculated in terms of hydrolytic acidity positively affected soil nutrient regime.

Thus, the content of alkali hydrolyzed nitrogen in the control variant (without fertilizers and defecation sludge) was $126.0 \mathrm{mg} / \mathrm{kg}$ soil, while with fertilizer ( $\left.\mathrm{N}_{\sharp} P_{\sharp} \mathrm{K}_{\mathrm{l}}\right) 133.0 \mathrm{mg} / \mathrm{kg}$ soil (Fig. 1).

When applied at the rate of $1.0 \mathrm{CaCO}$ by h.a $(4.9 \mathrm{t} / \mathrm{ha})$, defecation sludge did not contribute to a marked increase in nitrogen alkali hydrolyzed $(125.0 \mathrm{mg} / \mathrm{kg}$ ). Joint application of defecation sludge (by 
$\mathrm{pH}_{\mathrm{s}}$ ) and complete fertilizer as well as without fertilizer increased content of alkali hydrolyzed nitrogen in the soil only by $1.0-8.0 \mathrm{mg} / \mathrm{kg}$ of soil.

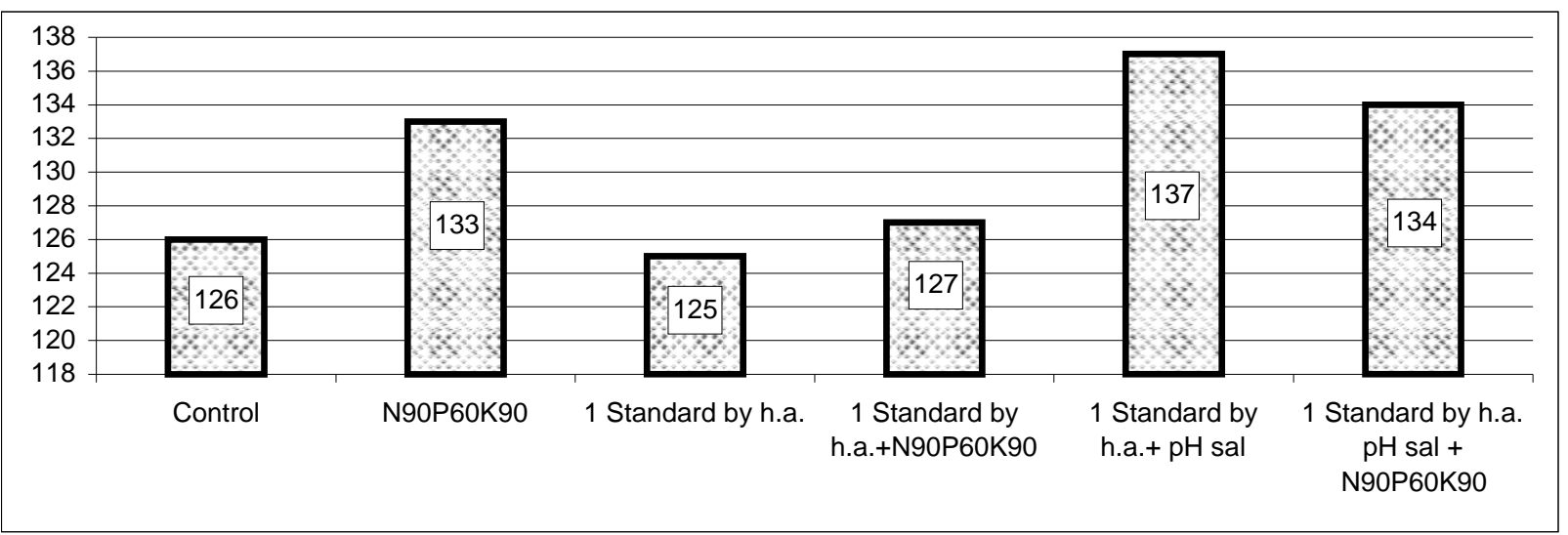

Figure 1. Effect of defecation sludge obtained by the new technology on the content of alkali hydrolyzed nitrogen in chernozem, $0-30 \mathrm{~cm}(\mathrm{mg} / \mathrm{kg}$ soil).

Application of defecation sludge at the rate of $1.0 \mathrm{CaCO}$ by h.a $(4.9 \mathrm{t} / \mathrm{ha})$ in one go with fertilizer $\left(\mathrm{N}_{\sharp} \mathrm{P}_{i} \mathrm{~K}_{\mathrm{K}}\right)$ increases nitrogen content to $137.0 \mathrm{mg} / \mathrm{kg}$ soil compared to control option by $11.0 \mathrm{mg} / \mathrm{kg}$.

Noteworthy is the fact that defecation sludge obtained by the new technology (cleaned of impurities) provides positive effect on the content of mobile phosphorus in leached chernozem. Thus, application of defecation sludge in autumn followed by disking of stubble and ploughing into the soil increases the content of mobile phosphorus in the test field soil up to $157.5-201.4 \mathrm{mg} / \mathrm{kg}$ (in the control treatment 147.4 $\mathrm{mg} / \mathrm{kg}$ and in the fertilization treatment $175.9 \mathrm{mg} / \mathrm{kg}$ of soil). Application of defecation sludge at the dose of $1.0 \mathrm{CaCO}$ calculated by h.a and $\mathrm{pH}_{\mathrm{s}}$ increased content of mobile phosphorus up to 184.4 and157.5 $\mathrm{mg} / \mathrm{kg}$ soil, respectively (Figure 2 ).

When applied defecation sludge at the dose of 1.0 by $\mathrm{pH}_{\sharp}$ in one go with $\mathrm{N}_{\sharp} \mathrm{P}_{\sharp} \mathrm{K}_{y}$ fertilizer, mobile phosphorus was $187.3 \mathrm{mg} / \mathrm{kg}$ soil.

The maximum content of mobile phosphorus was determined when applied 1.0 standard rate of the ameliorant calculated by h.a combined with mineral fertilizer $\mathrm{N}_{\sharp} P_{\sharp} K_{\mathbb{l}}(201.4 \mathrm{mg} / \mathrm{kg})$ indicating high level of provision of the crop.

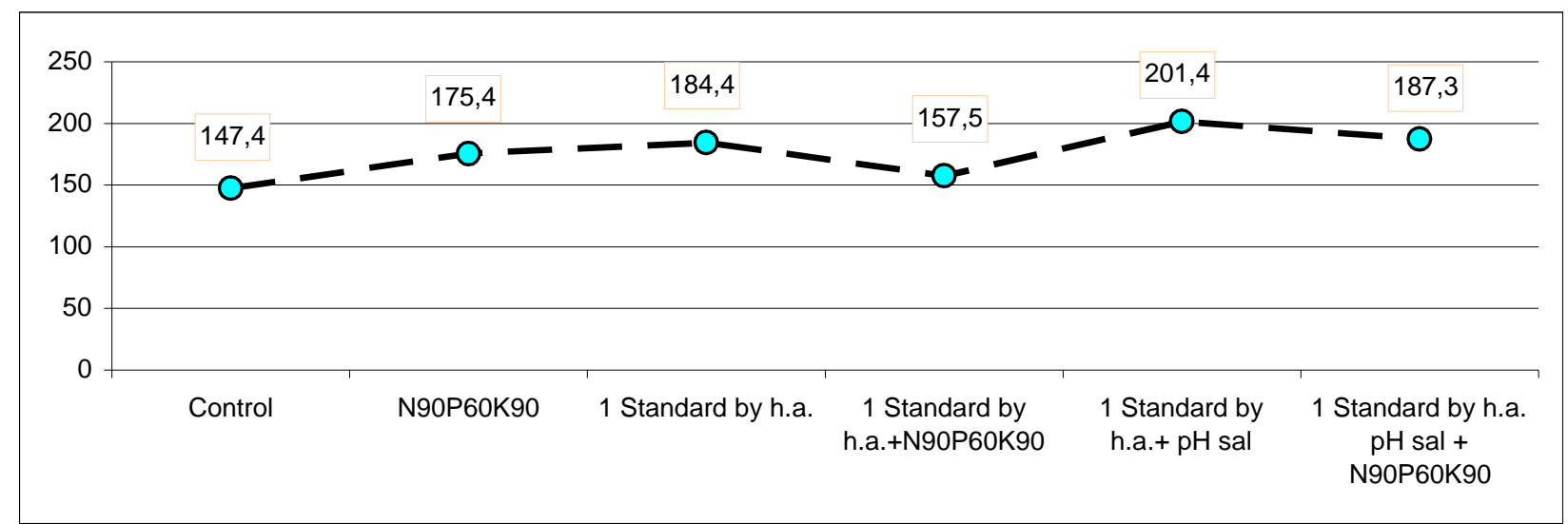

Fig. 2. Effect of defecation sludge applied under ploughing on the content of mobile phosphorus in chernozem, 0-30 cm ( $\mathrm{mg} / \mathrm{kg}$ soil).

In experiments on studying the effect of defecation sludge obtained by the new technology on potassium regime in slightly acidic chernozem, significant differences between the treatments (namely, control, without fertilizer and ameliorant) were found in exchangeable potassium content. Its content in the non-fertilized soil samples was $64.0 \mathrm{mg} / \mathrm{kg}$ soil. When applied defecation sludge at the rate of 1.0 
CaCO calculated by h.a and $\mathrm{pH}_{\sharp}$ in one go with mineral fertilizer $\left(\mathrm{N}_{\sharp} \mathrm{P}_{\sharp} \mathrm{K}_{\mathrm{K}}\right)$, exchangeable potassium content increased to 74.6 and $85.3 \mathrm{mg} / \mathrm{kg}$, respectively.

Application of $1.0 \mathrm{CaCO}$ by h.a along with mineral fertilizer $\left(\mathrm{N}_{\mathrm{N}} \mathrm{P}_{\mathrm{H}} \mathrm{K}_{\mathrm{n}}\right)$ increased exchangeable potassium content to $117.3 \mathrm{mg} / \mathrm{kg}$ of soil that was twice as much compared to non-fertilized treatment (Fig. 3).

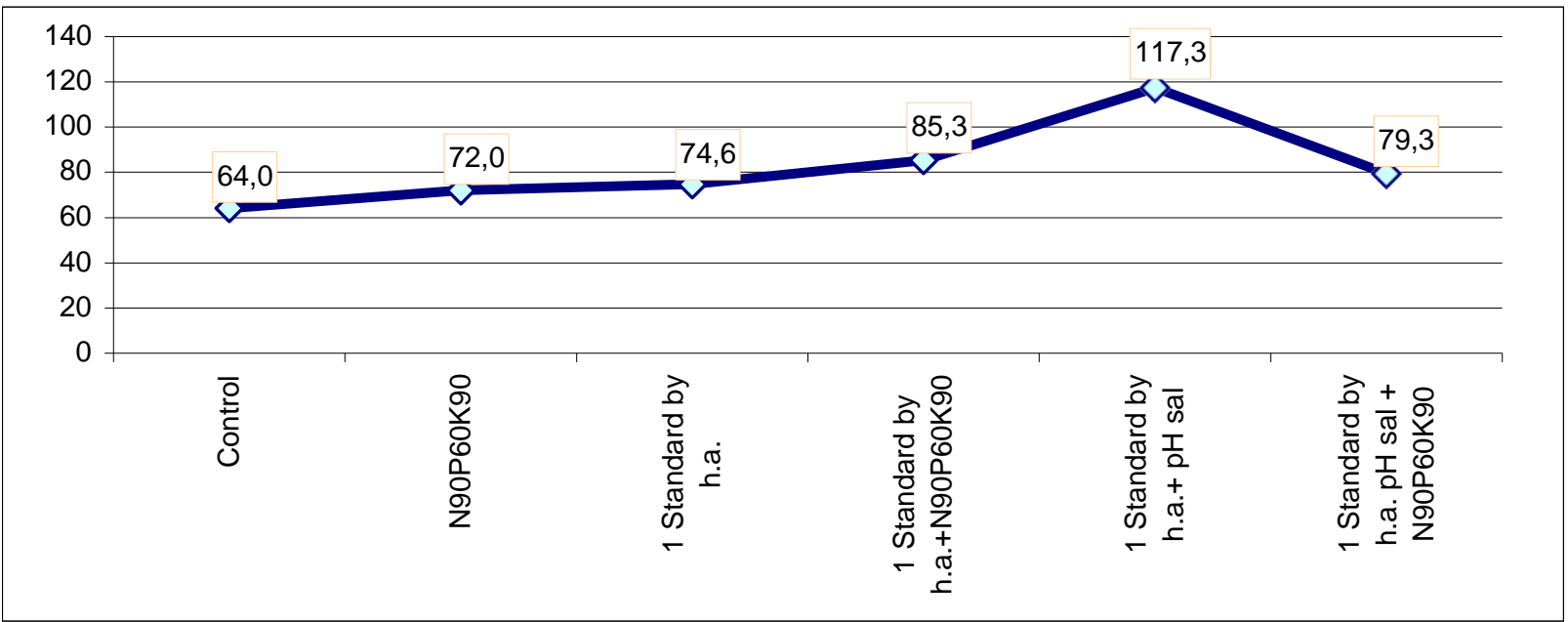

Fig. 3. Effect of defecation sludge on the content of exchange potassium in soil $(\mathrm{mg} / \mathrm{kg})$

Application defecation sludge at the rate of $1.0 \mathrm{CaCO}_{3}$ by $\mathrm{pH}_{\star}$ in one go with fertilizer contributed to a slight increase in the content of exchangeable potassium to $79.3 \mathrm{mg} / \mathrm{kg}$ soil, which is only $15.3 \mathrm{mg} / \mathrm{kg}$ soil higher when compared to non-fertilized control treatment.

Thus, application of defecation sludge at the rate calculated by hydrolytic acidity (h.a) appeared to be more effective that by $\mathrm{pH}_{s i}$ in terms of the content of essential nutrients in soil.

\section{Conclusion}

1. According to the research carried out in 2011-2013 under the conditions of the Central ForestSteppe of Ukraine, it was found out that application of defecation sludge in grain-row crop rotation improves nutrient regime of leached slightly acid chernozem.

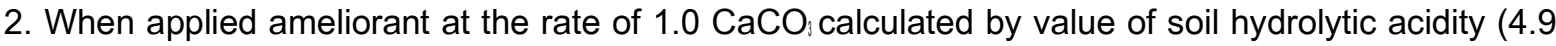
t/ha) in autumn followed by disking of stubble and ploughing into the soil, content of essential nutrients of the soil $(\mathrm{mg} / \mathrm{kg}$ ) increased, in particular nitrogen to 137.0 , mobile phosphorus to 201.4 exchange potassium to 117.3 , that is by $11.0,64.0$ and 53.3 higher compared to the control treatment, respectively.

3. Application of defecation sludge at the rate calculated in terms of $\mathrm{pH}_{\mathrm{s}}(3.7 \mathrm{t} / \mathrm{ha}$ in physical weight) along with fertilizers $\left(N_{\sharp} P_{i} K_{i}\right)$ according to the above mentioned technology was less effective than calculated in terms of hydrolytic soil acidity. The content of main nutrients in the soil increased (compared to the control treatment by $8.0,39.9$ and $15.0 \mathrm{mg} / \mathrm{kg}$ of soil, respectively.

\section{References}

1. Виттер. Б., Кольбе Г. Анализ достигнутого уровня в известковании. Witter B., Kolbe G. Analyse des erreichten standes in der kalkung. Falduirtschaft, 1973. № 10., s. 468-471.

2. Кнашис В.Ю. Эффрективность известкования почв Литовской ССР // Вопросы генезиса и плодородия почв Литовской ССР. - 1985. - С. 149-159.

3. Мязин Н.Т. Влияние применение удобрений и мелиорантов на показатели плодородия //Агрохимия - 1997. - № 2 - С. 26-30.

4. Мазур Г.А. Відтворення і регулювання родючості легких ґрунтів. Київ. Аграрна наука. -2008 . $-305 \mathrm{c}$. 
5. Польовий В., Деркач Н. Вплив вапнування і удобрення на відновлення родючості агрохімічно деградованих ґрунтів.//Вапнування і відтворення родючості ґрунтів в сучасних господарсько-економічних умовах. - 2012. - С. 16-18.

6. Чорний Д.Л., Чорна Л.І. Вплив добрив на агрохімічні показники родючості ґрунту і врожай залежно від вапнування. // Агрохімія і ґрунтознавство. - 1981. Вип. 42 - С. 27-30.

7. Польовий В Роль вапнування і удобрення у підвищенні землеробства західного Полісся // Вапнування і відтворення родючості ґрунтів в сучасних господарсько-економічних умовах. - 2012. C. 4-11.

8. Кирпичников Н.А., Глазунова Н.М. Приминение повыщенных доз извести с целью экономии фоссрорных удобрений в условиях центральных районов нечерноземной зоны РСФСР. Бюллетень Института удобрений и агропочвоведения им. Д.Н. Прянишникова (ВИУА). М. - 1986. —№ 78. — С. 28.

9. Шильников И.А., Кирпичников К.Л., Удалова Л.П., Гришин П.С., Пилипова Т.Е., Ивойлов В.В. Проблемы известкования почв // Химизация в сельском хозяйстве. - 1996. — № 5. - С. 18-21.

10. Шильников И.А., Удалова Л.П., Аканова Н.И., Козлова Т.А., Нестеров А.А. Эфффективность сочетания известкования и минеральных удобрений под зерновые культуры в длительном стационарном опыте. // Агрохимия. — 1997. —№ 4. - С. 34-39.

11. Методика исследований по сахарной свекле. - Киев ВНИС-292с. 